
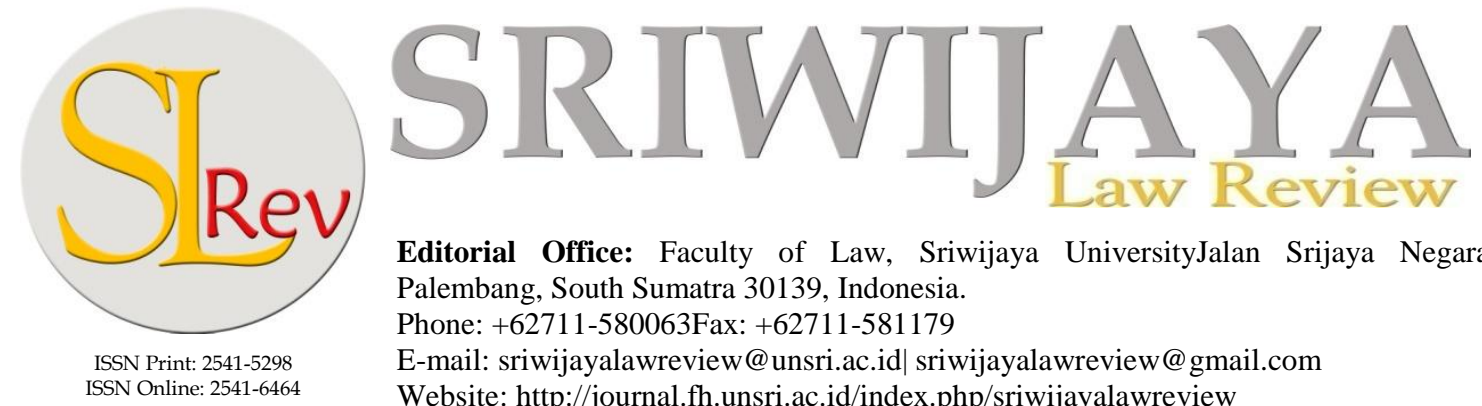

Editorial Office: Faculty of Law, Sriwijaya UniversityJalan Srijaya Negara, Palembang, South Sumatra 30139, Indonesia. Phone: +62711-580063Fax: +62711-581179

E-mail: sriwijayalawreview@unsri.ac.id|sriwijayalawreview@gmail.com Website: http://journal.fh.unsri.ac.id/index.php/sriwijayalawreview

\title{
Legitimacy as a Precondition for the Recognition of New Governments: A Case of Libya
}

\author{
Hamed Hasyemi Saugheh" and Rohaida Nordin ${ }^{* *}$
}

\begin{abstract}
Recognition of new Stets and governments is a political act with legal reverberations. Although the recognition of new States and governments is a traditional concept of international law but the challenging recognition of the transitional government of Libya proved that this traditional concept still can be highly exigent. Traditionally, the States in providing recognition to a new government follow their own benefits and privileges and rarely consider the structure, capacity and public support for the new government. If the rule of law and respecting democracy is going to be means of promoting peace and security is various areas of the world, is not it time to redefine the traditional concepts of international law (included of recognition of new States and government) from a new perspective? Considering the fact that, the existence of a legitimate authority in a group enhances the effective functioning of that group and reduces the internal conflicts, it seems that it is time to expand the political concept of legitimacy of the authorities into the international law. Is there any State practice to support the argument? In this article, the existence of norm creating forces and role of legitimacy in the recognition of the Libyan Transitional Government is going to be analysed. The After studying the role of legitimacy of the Libyan NTC in passing the sovereignty from the past regime to the new government by the international community, the effect of lack of legitimacy on the previous regime will be examined and the question of withdrawing of recognition of governments will be addressed.
\end{abstract}

Keywords: Recognition; Legitimacy; New Governments.

\section{ARTICLE HISTORY :}

\section{DOI: 10.28946/sIrev.Vol2.Iss1.111.pp69-81}

Received: Apr 11, 2017;

Reviewed: May 10, 2017;

Accepted: July 10, 2017;

Published: Jan 31, 2018;

Citation: V.2.1 SLRev. 2018.

Faculty of Law, Universiti Kebangsaan Malaysia, Bangi, Malaysia

E-mail :dr.hamedhashemi@gmail.com

* Faculty of Law, Universiti Kebangsaan

Malaysia, Bangi, Malaysia

E-mail: Rohaidanordin@yahoo.com

\section{INTRODUCTION}

Shaw defined recognition as "a method of accepting factual situations and endowing them with legal significance, but this relationship is a complicated one." 1 Actually, recognition is the reflection of the present governments of the world to current changes in the international scene. ${ }^{2}$ Rec-

\footnotetext{
1 Malcolm N. Shaw, International Law, New York: Cambridge University Press, 2003, p185.

${ }^{2}$ Yamali, N. What is meant by State Recognition in International Law. Ministry of Justice Turkey. [Online] Available from:
} 
ognition indicates fundamental corrections in geopolitics or the political system of a State. According to Yamali, recognition is a political act because the recognizing State, before giving recognition to the new entity, considers its own concerns and benefits, ${ }^{3}$ and recognition comes about in a doubtful atmosphere. Through recognition, a government reveals its cognition and true will about the situation in a State in a different vocabulary and according to its opinion. Glahn strongly believes that the process of recognition is not merely political but has legal consequences. ${ }^{4}$ In the Case of Guaranty Trust Co. v. the United States, the Supreme Court brought up the question of "which government should be recognized as the representative of the State?" and emphasised that this question should be answered by the political department of the government as it is not a judicial question. Sloane says that, although recognition is a political act of government, but in the recognition of new governments, legal norms and ethnic norms are considered. ${ }^{5}$ Van Essen acknowledged the duality of recognition of new governments, and separated the capacities of recognition into political and legal capacities. ${ }^{6}$ Through recognition, an

Http://www.justice.gov.tr/e-

journal/pdf/LW7081.pdf/ (retrieved: November 18, 2014).

${ }^{3}$ Yamali, N., Note 2.

${ }^{4}$ Gerhard Von Glahn et al. Law Among Nations, New York: Taylor and Francis, 2017, p147.

5 Sloane, R. D, 2006, "The Changing Face of Recognition in International Law: A Case Study of Tibet," Emory International Law Review, 16, p114.

6 van Essen, J., 2012, "De Facto Regimes in International Law, Utrecht Journal of International and European law, 28, p40. entity gets full state stature in international relations.

There are two main theories on the recognition of governments in international law, namely declaratory theory and constitutive theory. ${ }^{7}$ According to the constitutive theory, no entity is entitled to an international personality without recognition. ${ }^{8}$ Grant says that, the emergence of "a State depends on the actions [i.e. recognition] of existing states." From this perspective, recognition is the architect of the new government or State. According to Talmon, recognition of a new State has an absolutely constitutive effect on the recognition of its government because it is impossible to recognize a government without recognition of the State. $^{10}$

The problem with the constitutive theory is that firstly, a State or government "exists" whether it is recognized by other States or not. The purpose of the existence of governments is not to be recognized but to rule the country. Accepting the constitutive theory leads to the conclusion that other States and the international community are creating a new entity in a politically hazy atmosphere without any rationale behind the creation.

\footnotetext{
${ }^{7}$ Brownlie, I., Principles of Public International Law, Oxford: Oxford University Press, 1998, p92. 8 Martin Dixon, et al., Cases and Materials in International Law, Oxford: Oxford University Press, 2003, p154.

9 Thomas D. Grant, The Recognition of States: Law and Practice in Debate and Evolution, California: Praeger Publishers, 1999, p2.

${ }^{10}$ Stephan Talmon, Who is a Legitimate Government in Exile? Towards Normative Criteria for Governmental Legitimacy in International Law, the Reality of International Law, Essays in Honour of Ian Brownlie. Oxford: Clarendon Press, 1999, p502.
} 
Secondly, according to Brierly, the legal status of a new State or government that has the recognition of some countries and not of others remains obscure. ${ }^{11}$ One may not conclude that an entity in such a situation, like Israel that is recognized by the UN and the majority of States but not by a handful of Arab and Islamic States, is entitled to an international personality in its relations with those States that recognize it but not with those States that refuse to recognize it.

According to the declaratory theory, when an entity gains the essential elements ${ }^{12}$ of statehood, it comes into existence even if the existing States avoid recognizing it. In other words, the existence of a State or government is unconnected to its recognition, and recognition just reveals hidden truth and helps to unleash a new reality. This theory ensues from natural persons; just as individuals are born and come into this world free from recognition by law, the States and governments also emerge and their existence is free from recognition but their entitlement to rights is a prerequisite for recognition by the society and the legal system. Dixon defined the declaratory theory as "merely a political act recognizing a pre-existing state of affairs." $" 13$ The Brussels Resolution of 1936 by the Institute de Droit International on the recognition of new States and governments states that the existence of a new State or gov-

\footnotetext{
11 James leslie Brierly, The Law of Nations, Clarendon Press, Oxford, 1963, p138.

12 According to Montevideo Convention, the essential elements of States are included as: "a defined territory, permanent population and an effective government capable of entering into foreign relations", Charter of the Organization of American States. 1948. Art. 9.

${ }^{13}$ Martin Dixon, et al., Note 8, p154.
}

ernment does not depend on the recognition or non-recognition of other States. The Montevideo Convention of 1933, the Charter of the Organisation of American States of 1948, and the ICJ in its advisory opinion on the application of the Convention on the Prevention and Punishment of the Crime of Genocide, ${ }^{14}$ also support this theory. The Arbitration Commission of the Hague Conference on Yugoslavia expressly announced that recognition is declaratory. ${ }^{15}$ Brierly said it is possible for a State to come into existence without being recognized by other States "and it has a right to be treated by them as a State.",16 The problem with the declaratory theory is that when a State or government can come into existence without being formally recognized by the existing States, what is the effect of the recognition ${ }^{17}$ Talmon answered that the effect of the recognition from this perspective is a "confirming effect." 18 This theory does not explain why non-recognition of a State or government is effective when the existence of the State or government is independent of its recognition by other States. Put in another way, the theory is suitable for recognition but has fundamental delicacies on the non-recognition

\footnotetext{
${ }^{14}$ Application of the Convention on the Prevention and Punishment of the Crime of Genocide, Preliminary Objections, 1996, pp 661 and 686.

15 Bertrand G. Ramcharan, The International Conference on the Former Yugoslavia: Official Papers, Volume 2, Leiden: BRILL, 1997, Opinion No. 1, P 1259 and Opinion No. 8, p1284.

${ }^{16}$ James leslie Brierly, Note 11, p138.

17 Jure Vidmar, 2009, Democracy and State Creation in International Law, Nottingham: University of Nottingham, p61.

18 Stefan Talmon, 2004, "Constitutive Versus The Declaratory Theory of Recognition: Tertium Non Datur?," The British Yearbook of International Law, 75, p107.
} 
of States or governments. Moreover, the practices of the State do not support the theory, and under international law, new States or governments are not entitled to any rights before recognition. ${ }^{19}$

As mentioned above, both theories of recognition have some deficiencies. Lauterpacht tried to solve the problem by presenting a new definition for recognition. In his view, when "the conditions of statehood are met, the States are under a duty to recognize the new State." 20 This definition of recognition interferes with the political nature of recognition but the common trend of the international community is to endow recognition to the new State or governments through international conferences and/or organisations collectively.

In international law, States also recognize new governments. The difference between the recognition of a new State and a new government is that the latter is a duplication. On recognition of new entities in international law there are three categories: recognition of States, recognition of governments and recognition of belligerents. In recognition of States, other States and the international community examine if the new entity has the criteria for Statehood and what are the legal consequences of Statehood. In recognition of governments the question is that which group is able and may represent the country before the international community. In recognition of belligerents

19 William Thomas Worster, 2009, "Law, Politics and the Conception of the State in State Recognition Theory," Boston University International Law Journal, 75, p119.

20 Robert Jennings and Arthur Watts KCMG, Oppenheim's International Law, UK: Longman, 1955, Sec. 71. other States and international community will consider if the dissident armed group has met the criteria of belligerency and will try to put obligations under IHL on them. ${ }^{21}$

The difference between the recognition of States and governments is that it is enough that the present countries recognize the new State only once, but recognition of governments is (expressly or tacitly) repeated especially in cases of unconstitutional changes. ${ }^{22}$ If the authorities of a State fail to gain the recognition of other States and the international community, this non-recognition never undermines the international personality of the State. After recognition, new States enjoy a kind of permanence in view of the principles of non-intervention, selfdetermination and inviolability of borders in international law. Wolfrum says that when other governments recognise a new government, actually they are revealing their will in maintaining relationships with it. According to him the effect of recognition of new governments is that they will be accepted by the international community, their laws and regulations are recognised before the courts of the recognising States and the new governments will enjoy diplomatic immunities and privileges. $^{23}$

\footnotetext{
21. Louise Arimatsu \& Mohbouda Choudhury, 2014, "The Legal Classification of the Armed Conflicts in Syria, Yemen and Libya," Chatham House, p19.

${ }^{22}$ In other words, Brownlie said recognition of a new State may take the form of the recognition of a new government.

${ }^{23}$ Rudiger Wolfrum \& Christiane E. Philip, 2002, "The Status of the Taliban: Their Obligations and Rights under International Law," Max Planck Yearbook of United Nations Law, 6, pp569-71.
} 
According to traditional legal theory, the establishment of a new government through the constitutional process raises no questions concerning legitimacy and therefore, the recognition of that government. ${ }^{24}$ Harris says, there is no need for recognition in cases where changes have taken place in accordance with the Constitution of the State. ${ }^{25}$ Nevertheless, if a government gains power through nonconstitutional means, its recognition by other governments is doubtful until it is recognized by many States. ${ }^{26}$ Sloane says that, recognition of governments is a matter of legitimacy. ${ }^{27}$ According to d' Aspremnot an illegitimate government is never recognized as the representative of "the State of which it claims to be at the helm." 28 Sometimes it is not easy to discern which group is the government of the new State. For example, the African Union faced a lot of challenges concerning the accreditation of delegates of newly-formed governments that came to power unconstitutionally. ${ }^{29}$ OAU tried to solve the challenge by creating a link be-

\footnotetext{
${ }^{24}$ It has to be borne in mind that recognition of new states and governments is a political act and sometimes recognition is conferred to new entities where their legitimacy is under doubt because of political concerns.

25 D. J. Harris, 2004, Cases and Materials in International Law, London: Sweet \& Maxwell, p159.

26 M. J. Peterson, Recognition of Governments: Legal Doctrine and State Practice, London: Palgrave Macmillian. 1997, p3.

${ }^{27}$ Sloane, R. D, Note 5, p110.

28 J. d'Aspremont, 2006, "Legitimacy of Governments in the Age of Democracy." Journal of International Law and Politics, 38, P 902.

${ }^{29}$ Kofi Oteng Kufuor, 2002, "The OAU and the Recognition of Governments in Africa: Analysing its Practice and Proposals for the Future," American International law review, 17, p370.
}

tween democracy and recognition of new governments. ${ }^{30}$

In 1997, the OAU refrained from recognizing the military coup in Sierra Leone because army officers overthrew "the democratically elected civilian government." ${ }^{31}$ Moreover, the OAU, in a declaration known as the "African Union Declaration on the Principles Governing Democratic Elections in Africa", highlighted the fundamentals of a democratic government and the legality of democratic changes, and provided principles on the methods for organizing free and periodic elections. ${ }^{32}$

According to Wolfrum, recognition of belligerents is also categorised as implicit and explicit and their recognition is limited to armed conflict period. Moreover, it is possible that other governments or the government that the belligerents are fighting against recognised the belligerents. $^{33}$

\section{ANALYSIS AND DISCUSSION}

According to international law, the existing States in a particular situation are under an obligation to refrain from recognizing the political entity as a new State or government. There are two theories on the non-recognition of States and governments, namely prohibition of premature recognition and the doctrine of obligatory non-recognition. ${ }^{34}$

\footnotetext{
${ }^{30}$ The 1998 text presented to the Security Council by Secretary-General titled, "The Promotion of Durable Peace and Sustainable Development in Africa”, UN Doc. A/52/871-S/1998/318.

${ }^{31}$ Kofi Oteng Kufuor. Note 29. p388.

32 The 2013 African Union Declaration on Principles Governing Democratic Elections in Africa, Art(s) 2, 3 \& 4 AHG/Dec1.1.

${ }^{33}$ Wolfrum and Philip, Note 23, p580.

34 Jure Vidmar, Note 17, p61.
} 
In international law, there is no obligation to recognize new States and governments, but in some cases, there is an obligation to abandon recognition. ${ }^{35}$ Recognition of an entity that lacks the traditional conditions of statehood or governmental elements by the existing States is called "premature recognition." 36 The recognition of Bangladesh by India in 1971 are examples of new States that were positioned by premature recognition.

Non-recognition of new governments means refusal to acknowledge their existence, legality or validity. Vidmar says that, the doctrine of obligatory nonrecognition is about non-recognition of entities that have satisfied the traditional conditions of statehood or governance but their establishment is illegal. ${ }^{37}$ According to Lauterpacht, the fabrication of the nonrecognition of illegal situations is because the illegal situations cannot become a reference of legal rights for the lawbreaker. ${ }^{38}$ Put differently, if international law is considered as the language of the international community, then these illegal entities are acting out of norm and are trying to speak a new language. The recognition of illegal entities as new States or governments is a violation of the right to self-determination of nations, and may trigger regional violence. It may endanger international peace and security because there are many territorial pleas and mi-

35 Jure Vidmar, 2012, "Explaining the Legal Effects of Recognition," International and Comparative Law Quarterly, 62 (2), P380.

36 Jure Vidmar, Note 17, p65.

37 Jure Vidmar, Note 17, p66.

38 Hersch Lauterpacht, 1947, Recognition in International Law, UK: Cambridge University Press, p420. norities seeking independence, and this endangers them by subjecting them to exploitation by the mega powers.

The first precise case of nonrecognition was the state of Manchukuo in China, which was seized by Japan in 1931. Although a handful of States, such as Poland and Spain, recognized it, the League of Nations abstained from giving recognition. The measures taken by the United Nations against the ruling military governments in Haiti and Sierra Leone and the non-recognition of Southern Rhodesia in 1965 were cases in which the doctrine of obligatory non-recognition was applied. ${ }^{39}$ In 1975, the UN refrained from granting recognition to the merger of East Timor with Indonesia. ${ }^{40}$ In the 2000s, many international organisations, such as NATO and the Council of Europe, abstained from recognizing South Ossetia and Abkhazia to affirm the territorial integrity of Georgia. The latest case of non-recognition of a new State and government might be the case of Crimea. It is evident that in cases of illegally-created entities and situations, the doctrine of obligatory non-recognition is applicable, and other States should refuse to recognize the illegal entity collectively. ${ }^{41}$ The principle of collective nonrecognition is spelled out in Article 41 of the International Law Commission Articles on State Responsibility.

Due to the increasing number of democratic States after the Cold War, there

\footnotetext{
${ }^{39}$ Gregory H. Fox and Brad R. Roth, 2000, Democratic governance and International Law, UK: Cambridge University Press, p343.

${ }^{40}$ K ennith Christie and Denny Roy, 2001, The Politics of Human Rights in East Asia, London: Pluto Press, p188.

${ }^{41}$ Jure Vidmar, Note 17, p66.
} 
seems to be a common trend in international society to use democracy as an essential element for recognizing new states and governments. Some authors claim that "the obligation of a non-illegal entity is an obligation owed erga omnes." $" 42$ The holding of a democratic referendum by an entity is an important step in the recognition policy of the international community but it is not conclusive. For the international community, besides the legitimacy of the government, stability and development are also important factors to consider in the recognition of new States and governments.

\section{Succession of the Gadhafi Regime by the Libyan NTC in the General As- sembly of the United Nations}

At the $66^{\text {th }}$ session of the UN General Assembly (GA), the Committee of Credentials recommended that the members grant the seat of Libya to the National Transitional Council of Libya (NTC). ${ }^{43}$ At that session, interesting questions were discussed.

The opponents rendered the seat of Libya to the NTC based on the rules of the GA about the Credentials Committee and political concerns. In the opinion of the representative of Angola, representing the Southern African Development Community (SADC), according to Rule No. 27 of the UNGA, the head of State or government or the foreign minister of the State should sign the credentials. Then he asked the question: "Who signed the NTC

\footnotetext{
${ }^{42}$. J. Vidmar, Note 17, p66.

${ }^{43}$ General Assembly of United Nations. 2013. Session Archives. Available from: http://gadebate.un.org/sessions-archive/66. date of access [Retrived: June 5,2013].
}

credentials that were accepted by the Credentials Committee?"44

The representative of Venezuela, Ambassador Valero, based his reason on political concerns. He said, he believed that the Libyan NTC was a puppet group led by NATO forces and some western powers, and was not genuinely representing the people of Libya. ${ }^{45} \mathrm{He}$ and some media said that the NTC was a designated government, and the fact that its capacity and competence were always under question backed this view. ${ }^{46}$

The representative of Bolivia cited that his government was unsure if the Libyan NTC was the legitimate representative of the Libyan people because the people of Libya had not yet had the opportunity to express their will. He added that the United Nations was being manipulated into a foreign, armed intervention in Libya but the Libyan people who continued to suffer, had not yet had the chance to express their opinions and to set up their own legitimate Government

\footnotetext{
${ }^{44}$ GA. Note 43.

${ }^{45} \mathrm{GA}$. Note 43.

${ }^{46}$ Huffington Post. 2013. E. M. Lederer. Libya National Transitional Council: UN Approves Seat for former Rebels. Available from: www.huffingtonpost.com/2011/09/16/libyanational-transitiona-council-un-n-966339.html. [Retrieved: June 20, 2013]. Chathamhouse. 2013. Libya Working Group Report. Libya: Challenges after Liberation. Available from: www.chathamhouse.org [Retrieved: July 6, 2013]. Pan African News Wire. 2011. A. Aziki. 2.11. Libyan Forces Regroup to resist Puppet Regime. Available from: www.workers.org/2011/world/libya-1117 Available from: [July 6, 2013]. Information Clearing House. 2013. A. E. Torbat, The Neocolonial Order is to Stay: A Puppet Government in Libya. Available from: www.informationclearing house.infolarticle29201.htm.
} 
to represent their interests. ${ }^{47}$ The representative of Granada said the necessary conditions for recognizing the NTC had not been aggregated yet, and this recognition would be premature ${ }^{48}$.

At the $66^{\text {th }}$ session of the UN General Assembly, the opponents to the recognition of the Libyan NTC, such as Egypt, voiced their political concerns. The representative of Egypt asked the member States to recognize the NTC in order to support the ideals of the Libyan people. ${ }^{49}$

The representative of Gabon answered the question of the legitimacy of the NTC. In his opinion, the Libyan NTC supported the people of Libya since the beginning of the upheaval, and the other States individually recognized it as the legitimate representative of the Libyan people. $^{50}$ The representatives of Senegal and Chad said that the Libyan NTC made great efforts to improve the humanitarian situation and supported the movement of the Libyan people towards freedom. In their opinion, these efforts should be rec-

\footnotetext{
${ }^{47}$ United Nations. 2015. Available from: www.un.org/press/en/2011/gal1137.doc.htm and edition.cnn.com/2011/world/Africa/09/16/un.libya. [Retrieved: February 18, 2015].

${ }^{48}$ Reuters. $2015 . \quad$ Available from: www.reuters.com/article/2011/09/16/us-libya-unassembly-idustre78f4qa20110916 [Retrieved: February 18, 2015].

${ }^{49}$ Reuters. $2015 . \quad$ Available from: www.reuters.com/article/2011/09/16/us-libya-unassembly-idustre78f4qa20110916 [Retrieved: 18 February 2015].

50 www.un.org/press/en/2011/ga11137.doc.htm accessed [18 February 2015] and General Assembly of United Nations, 'General Assembly Seats National Transitional Council of Libya as Countries Representative for Sixty-Sixth Session', GA/11137.
}

ognized. ${ }^{51}$ Arguably, the representative of Senegal provided a moral reason for insisting on the cogency of the recognition of Libya.

On 16 September, the Libyan NTC was recognized by the UN General Assembly $^{52}$ as the legitimate representative of the Libyan people, and took the seat of Libya in the General Assembly. This recognition invalidated the diplomatic position of the Gaddafi delegates in favour of those who represented the NTC. After the recognition of the Libyan NTC by the General Assembly, the African Union in late September recognized the Libyan NTC as the "sole representative of the Libyan people" if they formed an inclusive transitional government. ${ }^{53}$ The recognition of the NTC by the UN and the AU were wise decisions because according to Bangerter, abstention from the recognition of such an impressive group that was not an extremist group posed the danger of the nature of the council being changed into that of a terrorist group. ${ }^{54}$ Thus, recognition played a key role in the future of the NTC and the destiny of Libya.

Recognition is a unilateral act and States cannot recognize the new entity on behalf of each other. In other words, the

\footnotetext{
${ }^{51}$ United Nations. 2015. Available from: www.un.org/press/en/2011/gal1137.doc.htm [Retrieved: February 18, 2015].

${ }^{52}$ With 17 against, 114 voting in favour, 47 absent and 15 abstentions. United Nations. Note 52.

53 Sithole, 2013, "The African Union Peace and Security mechanism's crawl from design to reality: Was the Libyan crisis a depiction of severe limitations?" African Journal on Conflict Resolution, 12, p158.

${ }^{54}$ Bangerter, 2011, "Reasons why Armed Groups Choose to Respect International Humanitarian Law or not," International Review of the Red Cross, 93, p378.
} 
right to recognition of new States/governments is not transferable. ${ }^{55}$ Thus, in collective recognition, the individuality of recognition is respected and States which abstained from recognizing the new entity are not committed to establish diplomatic relations and do not consider sovereign rights and immunities for the new entity. Collective recognition provides the opportunity for the international community to apply new standards, such as a democratic mandate and respect for human rights, for the recognition of new governments. ${ }^{56}$ This recognition may be purely a legal recognition and on applying it, just legal factors should be taken into consideration, although in the case of the recognition of the Libyan NTC, political and moral concerns played a fundamental role.

If the goal of recognising the new States and governments is the establishment of diplomatic and economic relations $^{57}$ with the new entity or stabilizing the new situation, this goal can be met by individual recognitions provided by the States (act of recognition). The collective recognition of the new government by an international governmental institution, such as the UN General Assembly, upgrades the new regime to a higher level. ${ }^{58}$

\footnotetext{
55 Johnson \& W. Lin, Taiwan and Recognition under US and International Law: A Legal Perspective, PhD Thesis: National San Yat-sen University, 2012, p125.

${ }^{56}$ G. Pope Atkins, Encyclopaedia of the InterAmerican System, Westport: Greenwood Publishing Group, Westport, 1997, P128 and Percy E. Corbett, The Growth of World Law, Princeton: Princeton University Press, 2015, p129.

${ }^{57}$ Christopher C. Joyner, International Law in the $21^{\text {st }}$ Century: Rules for Global Governance, Oxford: Rowman \& Littlefield, 2005, p48.

58 Daniel Hogger, The Recognition of States, Musnter: LIT Verlag Munster, 2015, p17.
}

The individual policies and privileges of States may be achieved through individual recognition, while the recognition by the international governmental institution indicates the legal and correct attitude of the new government. ${ }^{59}$

If collective recognition has the same political motivations as individual recognition, then why should a State recognize a new government individually and then vote for it in a collective recognition? Collective recognition is not simply rendering the seat of the State to the new government; it reflects the greater reality that the international community is confident that the new government is able to shoulder its international responsibilities. ${ }^{60}$ Moreover, collective recognition puts an end to doubts concerning the continuity of the political and legal status of the former regime; it is like burning a candle at both ends, i.e. the former regime loses its status both internally and externally.

Through the collective recognition of the new government, the international community comes to the judgment that the new regime deserves to actively play an effective role on the international

\footnotetext{
59 There are also opponents to the idea of "collective recognition", for example, in 1950; the Secretary General of the United Nations denied the existence of the notion of "collective recognition" by the UN. Whether we call it "collective recognition" or "admittance by the UN", this act has the same legal consequences as individual recognition by States and moreover, it is effective in settling disputes. See David Raic, Statehood and the Law of Self-Determination, Boston: Martinus Nijhoff Publishers, 2002, p42. On the other hand, scholars such as Ian Brownlie identified the existence and legality of "collective recognition", James Crawford, Brownlie's Principles of International Law', Oxford: Oxford University Press, 2012, p150.

${ }^{60}$ Malcolm N. Shaw. Note 1. p336.
} 
scene, whether it is supported by the international community or not. Individual recognition of the new government is political recognition; collective recognition is recognition by international law. A study of the process of recognition of the Libyan NTC provides a good example of the collective recognition of a new government.

Recently, "Universal Recognition" was debated within the context of the UN. ${ }^{61}$ Universal recognition still needs transparency. The difference between "universal recognition" and "collective recognition" should be considered. For universal recognition, it should be noted that in the international community there is always friction among the sovereignties. Universal recognition leads to the recognition of the new government on behalf of other States. It is inconsistent with the principle of non-intervention in the domestic affairs of other States as provided for in the UN Charter and the Declaration of the Principles of International Law Concerning Friendly Relations between States.

It is suggested that instead of using the expression "universal recognition", the expression "collective recognition" should be used because it matches the current realities of the international community. In 1971, the ILC defined collective recognition as occurring when States act collectively on a specific situation, evaluate the related information and come to a decision. ${ }^{62}$ Usually, the groups of

\footnotetext{
${ }^{61}$ Malcolm. N. Shaw, Note 1. p336.

62 The 1971 International Law Commission, 'Document - A/CN. 4/245, Survey of International Law - Working Paper prepared by the SecretaryGeneral in the light of the decision of the
}

States, via an official conference or meeting, announce their recognition of the new situation or entity. Collective recognition simplifies and catalyses the transition of the society ${ }^{63}$ to democracy and respect for human rights.

The process of the recognition of the Libyan NTC also proves that recognition still is a vibrant notion of international law and it is becoming more and more complex each day because of the addition of new layers of human rights to international law. International law is a law of recognition; every situation, rule, agreement and government should be recognized under this law. The case of the recognition of the Libyan NTC also proves that recognition is an intentional, optional and political act that no group can force onto other States and the international community.

\section{Recognition of the Libyan NTC; With- drawal of Recognition of the Gadhafi Regime}

Concerning the recognition of the Libyan NTC as the legitimate representative of the Libyan people, was the act of the Libya Contact Group in asking the participating States to revoke the political position of the Gaddafi delegates ${ }^{64}$ equivalent to the withdrawal of recognition of the de jure government of Libya? If the answer is yes, then it is inconsistent with the current rules of international law

Commission to review its program of work', Yearbook of International Law, Vol. II, p18.

63. Jure Vidmar, Democracy and State Creation and State Creation in International Law, 2009, Nottingham: University of Nottingham, $\mathrm{PhD}$ Thesis, p17 and 93.

${ }^{64}$ The 2000 United Nations Security Council, Resolution 1325, 2000, S/RES/1325. 
on the recognition of States as it is not possible to withdraw the de jure recognition of already recognized governments.

De jure recognition cannot be withdrawn because the ruling government is the legitimate representative of the people and a symbol of the incarnation of their right to self-determination. The withdrawal of de jure recognition is a violation of the rule of non-intervention in the domestic affairs of States and their independence that is upheld in Article 2 (7) of the UN Charter. Thus, should the opinion of Posner and Sykes ${ }^{65}$ be adopted that the recognition of the Libyan NTC was a withdrawal of the recognition of the Gaddafi regime and was therefore in violation of the UN Charter?

Governments should represent their people. A group is in power because the people support them. The elites rule the country and make decisions for the whole population because the people have allowed them to do so. When a government fights its own people, it means that the government has lost its representation and legitimacy. When a government is in power, its legitimacy is continuous until it commits mass crimes against its population. ${ }^{66}$ This means that people no longer allow them to remain in power. The government becomes deplete of legitimacy. Arguably, what the Libya Contact Group did was not a withdrawal of recognition of a de jure government but it was a pronouncement of the current situation in Libya.

\footnotetext{
65 Eric A. Posner \& Alan O. Sykes, Economic Foundations of International Law, Cambridge: Harvard University Press, 2013, Chapter 14.

${ }^{66}$ Stephan Talmon. Note 10. p512.
}

The Libya Contact Group did not withdraw recognition of the Gaddafi regime, but the Gaddafi regime withdrew itself from legitimacy by committing mass atrocities against its own people. The Libya Contact Group just announced the transmission of power to the new group. The withdrawal of de jure recognition is different from announcing the fact that a group has lost its legitimacy because of its own violations and malfunctions. The withdrawal of recognition is ignoring the sovereignty of a nation, but announcing the loss of legitimacy is supporting the people's right to revolution and to democracy. In the case of Libya, the recognition of the Libyan NTC was announced at the same time as the declaration of the loss of legitimacy of the Gaddafi regime because the Libya Contact Group did not want to be accused of overlooking the sovereignty of Libya. Thus, it may be concluded that the Libyan NTC replaced the Gaddafi regime by respecting the sovereignty, independence and the fundamental human rights of the Libyan people. Recognition of the new government is withdrawal of the recognition of the old regime without violating the sovereign rights of the people on their land.

\section{CONCLUSIONS}

Recognition of the Libyan NTC proves that recognition still is a vibrant notion of international law. At the $66^{\text {th }}$ session of the UN General Assembly the question of the legitimacy of the NTC was raised and the Libyan NTC was recognized as the legitimate representative of the Libyan people. The provided recognition to the Libyan NTC was collective recognition. 
States in providing individual recognition to the new government follow their policies and try to achieve privileges, while the collective recognition indicates the legal and correct attitude of the new government. Collective recognition of a new government can be used as a method of supporting democracy and promoting human rights. It simplifies and catalyses the transition of the society to democracy and respect for human rights. Moreover, puts an end to doubts concerning the continuity of the political and legal status of the former regime.

Universal recognition is not a correct expression for addressing the recognition provided by international organizations such as GA. It is suggested that instead of using the expression "universal recognition", the expression "collective recognition" should be used because it matches the current realities of the international community.

Gadhafi regime by fighting its own people lost its representation and legitimacy. Revoking the political position of the Gaddafi delegates was not equivalent to the withdrawal of recognition but

the government becomes deplete of legitimacy. Considering the fact that withdrawal of recognition of a de jure governments is against right to selfdetermination and interning in internal affairs of States, arguably, what the Libya Contact Group did was not a withdrawal of recognition of a de jure government but it was a pronouncement of the current situation in Libya. The Libya Contact Group just announced the transmission of power to the new group.
Arimatsu and Mohbouda. 2014. "The Legal Classification of the Armed Conflicts in Syria, Yemen and Libya," Chatham House.

Bangerter. 2011. "Reasons why Armed Groups Choose to Respect International Humanitarian Law or not," International Review of the Red Cross.

Brierly,James leslie. 1963. The Law of Nations, Oxford: Clarendon Press.

Brownlie, Ian. 1998. Principles of Public International Law, Oxford: Oxford University Press.

Corbett, Percy E. 2015. The Growth of World Law. Princeton: Princeton University Press.

d'Aspremont. 2006. "Legitimacy of Governments in the Age of Democracy." Journal of International Law and Politics.

Christie, Kennith and Denny Roy. 2001. The Politics of Human Rights in East Asia. London: Pluto Press.

Dixon, Martin and Robert Mc Corquodale. 2003. Cases and Materials in International Law, Oxford: Oxford University Press.

D. J. Harris, 2004, Cases and Materials in International Law, London: Sweet \& Maxwell.

Fox, Gregory H. and Brad R. Roth. 2000. Democratic governance and International Law. UK: Cambridge University Press.

G. Pope, Atkins.1997. Encyclopaedia of the Inter-American System. Westport: Greenwood Publishing Group, Westport.

Grant,Thomas D. $1999 . \quad$ The Recognition of States: Law and Practice in Debate and Evolution, California: Praeger Publishers.

\section{REFERENCES}


Hogger, Daniel. 2015. The Recognition of States, Musnter: LIT Verlag Munster.

Jennings, Robert and Arthur Watts KCMG. $1955 . \quad$ Oppenheim's International Law, UK: Longman.

Joyner, Christopher C. 2005. International Law in the $21^{\text {st }}$ Century: Rules for Global Governance. Oxford: Rowman \& Littlefield.

Kufuor. 2002. "The OAU and the Recognition of Governments in Africa: Analysing its Practice and Proposals for the Future," American International law review.

Lauterpacht, Hersch. 1947. Recognition in International Law. UK: Cambridge University Press.

M. J. Peterson. Recognition of Governments: Legal Doctrine and State Practice. London: Palgrave Macmillian. 1997.

Posner, Eric A. and Alan O. Sykes. 2013. Economic Foundations of International Law, Cambridge: Harvard University Press.

Raic, David. 2002. Statehood and the Law of Self-Determination, Boston: Martinus Nijhoff Publishers.

Ramcharan. 1997. "The International Conference on the Former Yugoslavia: Official Papers." BRILL.

Shaw, Malcolm N. 2003. International Law. New York: Cambridge University Press.

Sithole. 2013. "The African Union Peace and Security mechanism's crawl from design to reality: Was the Libyan crisis a depiction of severe limitations?" African Journal on Conflict Resolution..

Sloane. 2006. "The Changing Face of Recognition in International Law: A
Case Study of Tibet," Emory International Law Review.

Talmon. 2004. "Constitutive Versus The Declaratory Theory of Recognition: Tertium Non Datur?," The British Yearbook of International Law.

Talmon,Stephan. 1999. Who is a Legitimate Government in Exile? Towards Normative Criteria for Governmental Legitimacy in International Law, the Reality of International Law, Essays in Honour of Ian Brownlie. Oxford: Clarendon Press.

Van Essen, 2012. "De Facto Regimes in International Law," Utrecht Journal of International and European law, 28.

Vidmar, Jure. 2009. Democracy and State Creation in International Law. Nottingham: University of Nottingham.

Vidmar. 2012. "Explaining the Legal Effects of Recognition," International and Comparative Law Quarterly.

Von Glahn, Gerhard.2017. Law among Nations. New York: Taylor and Francis.

Wolfrum and Philip. 2002. "The Status of the Taliban: Their Obligations and Rights under International Law," Max Planck Yearbook of United Nations Law.

Worster. 2009. "Law, Politics and the Conception of the State in State Recognition Theory," Boston University International Law Journal. 